\title{
Rift Valley fever in kidney transplant recipient returning from Mali with viral RNA detected in semen up to four months from symptom onset, France, autumn 2015
}

F Haneche ${ }^{1}$, I Leparc-Goffart ${ }^{2}$, F Simon ${ }^{3}$, M Hentzien ${ }^{1}$, V Martinez-Pourcher ${ }^{1}$, E Caumes ${ }^{14}$, M Maquart ${ }^{24}$

1. Service de maladies infectieuses et tropicales, CHU Pitié-Salpêtrière, Paris, France

2. Centre National de Référence des Arbovirus, Institut de Recherche Biomédicale des Armées Marseille, France

3. Pathologie infectieuse et tropicale, Hôpital d'Instruction des Armées Laveran, Marseille, France

4. These authors contributed equally to this article

Correspondence: Fatiha Haneche (haneche.fatiha@gmail.com)

Haneche F, Leparc-Goffart I, Simon F, Hentzien M, Martinez-Pourcher V, Caumes E, Maquart M. Rift Valley fever in kidney transplant recipient returning from Mali with viral RNA detected in semen up to four months from symptom onset, France, autumn 2015. Euro Surveill. 2016;21(18):pii=30222. DOI: http://dx.doi. org/10.2807/1560-7917.ES.2016.21.18.30222

A 29-year-old kidney transplant recipient returning from Mali was diagnosed with Rift Valley fever (RVF) in France in autumn 2015. The patient was immunosuppressed due to his renal transplant. IgM and IgG specific to RVF virus (RVFV) were detected in cerebrospinal fluid and blood up to two months after symptom onset, whereas in urine, RVFV genomic RNA was detected by RT-PCR up to three months, and in semen up to four months post symptom onset.

We report a human case of Rift Valley fever (RVF) imported from Mali to France in an immunosuppressed patient after renal transplantation three years earlier, and detail the laboratory findings.

\section{Case report}

A 29-year-old kidney transplant recipient originating from Mali and having lived in France for five years, visited friends and relatives in Dionkoulané (Kayes region, Mali) from mid-August 2015 onwards. A month later, he started to have fever, chills and fatigue (day 1) and consulted a general practitioner (GP) in Mali. He was empirically treated with intravenous quinine for three days. His clinical status improved so he was able to return to France eleven days later.

At the end of September 2015 (day 12), he was admitted to Pitié-Salpêtrière University Hospital in Paris for asthenia and hypothermia $\left(35.5^{\circ} \mathrm{C}\right)$. The results of the clinical examination were normal. The liver function tests showed a severe cytolysis (aspartate aminotransferase: 12.44 international units (IU)/L (norm: 20-32), alanine aminotransferase: $1.236 \mathrm{IU} / \mathrm{L}$ (norm: 16-35)) with anicteric cholestasis (gamma glutamyl transpeptidase: $652 \mathrm{IU} / \mathrm{L}$ (norm: 12-55), alkaline phosphatase: $170 \mathrm{IU} / \mathrm{L}$ (norm: 40-120), total bilirubin: $9 \mathrm{IU} / \mathrm{L}$ (norm: 2-17)), and without liver failure (prothrombin time: $100 \%$, factor V: $99 \%$ ). Hepatitis B virus DNA PCR (COBAS AmpliPrep/COBAS TaqMan HBV test v2.0 Roche) was at the positivity threshold, i.e. $20 \mathrm{IU} / \mathrm{L}$. Hepatitis B surface antigen (HBs-AG) was negative, HBs and HBC IgG antibodies (ARCHITECT AgHBs qualitative II, Anti-HBs, Anti-HBc II, Abbott) were previously known positive. PCR detection of other viruses (hepatitis C, D and E, human immunodeficiency virus (HIV), herpes simplex virus) in blood was negative as well as hepatitis A virus IgM, HCV and HIV serologies. Epstein-Barr virus and cytomegalovirus PCR in blood were weakly positive. The patient was treated with entecavir due to suspicion of acute hepatitis $B$. The treatment was stopped after one week when the diagnosis was ruled out. Meanwhile, liver enzymes had returned to normal limits, and hepatic ultrasound scan did not show gallstones. He was discharged on day 17 with a temperature of $36.8^{\circ} \mathrm{C}$.

On day 44 , he was hospitalised again, this time presenting with delirium, fever $\left(38.8^{\circ} \mathrm{C}\right)$, headache, neck and back pain but no other neurological deficit and no visual loss. Lumbar puncture showed a lymphocytic meningitis (Table).

Two further lumbar punctures were carried out on day 48 and day 52. Cerebrospinal fluid (CSF) and serum were sent to the French National Reference Center for Arboviruses in Marseille. A magnetic resonance imaging (MRI) scan of the patient's brain on day 60 showed signs of pachymeningitis. Cryptococcal antigen and JC polyomavirus PCR were negative in blood and CSF. Given that the patient came from a tuberculosis endemic country, tuberculosis was considered and a pulmonary CT-scan and a bronchoscopy were performed for detecting pulmonary localisation. The bronchoscopy showed signs of intra-alveolar haemorrhage but the CT-scan 
Results of cerebrospinal fluid, serology and RT-PCR follow-up in a transplant recipient with Rift Valley fever after a travel to Mali, France, January 2016

\begin{tabular}{|c|c|c|c|c|c|c|c|}
\hline \multicolumn{2}{|c|}{ Day from first physician visit } & Day 44 & Day 48 & Day 52 & Day 74 & Day 117 & Day 145 \\
\hline \multirow{4}{*}{ CSF } & $\operatorname{Protein}(\mathrm{g} / \mathrm{L})$ & 1.41 & 1.02 & 1.1 & ND & 0.6 & ND \\
\hline & Cells $/ \mathrm{mm}^{3}$ & 211 & 71 & 199 & ND & 37 & ND \\
\hline & Lymphocytes & $60 \%$ & $97 \%$ & $99 \%$ & ND & ND & ND \\
\hline & RVF antibodies & ND & ND & $\begin{array}{l}\text { IgMpos } \\
\text { IgG neg }\end{array}$ & ND & $\begin{array}{l}\text { IgM pos } \\
\text { IgG neg }\end{array}$ & ND \\
\hline \multicolumn{2}{|c|}{ RVF antibodies in blood } & $\begin{array}{c}\lg M \text { and } \operatorname{IgG} \\
\text { pos }\end{array}$ & ND & ND & IgM and IgG pos & IgM and IgG pos & IgMand IgGpos \\
\hline \multirow{2}{*}{ PCR } & Semen & ND & ND & ND & Pos & Pos & Neg \\
\hline & Urine & ND & ND & ND & Pos & $\mathrm{Neg}$ & ND \\
\hline
\end{tabular}

CSF: cerebrospinal fluid; ND: Not done; Neg: negative; Pos: positive; RVF: Rift Valley fever.

was normal. The tuberculin skin test and QuantiFERON test were negative. However, the clinical presentation of lymphocytic meningitis with pachymeningitis in an immunocompromised patient originating from a tuberculosis endemic region, led us to consider tuberculosis meningitis in the absence of an alternative diagnosis. Treatment with anti-tuberculosis drugs was initiated on day 62 but stopped three days later because results for RVF ELISA serology in CSF taken on day 52 were positive for IgM and IgG antibodies.

The in-house qualitative RVFV ELISA is based on the same technic developed by Peyrefitte and al [1]. for dengue virus, including positive and negative serum controls confirmed by serum neutralisation test. RVF antigens are produced from a RVFV strain isolated in 2003 from a patient from Chad. Specificity of the RVFV antibodies detected was confirmed by a $50 \%$ neutralisation titre of $1 / 160$ for RVFV (strain Chad 2003) using the virus neutralisation test described by Swanepoel et al. [2].

Semen and urine collected on day 74 were positive (Cycle threshold (Ct) 36.40 and 35.20 , respectively) for RVFV, using a RVFV quantitative real-time reverse transcription-PCR assay (Taqman RT-PCR) developed by Bird et al. [3] but faeces and saliva collected on day 82 tested negative. Isolation of the virus was unsuccessful so the RVFV strain could not be sequenced.

Upon establishment of the diagnosis on day 63, we stopped mycophenolate mofetyl and doubled prednisone (from $7.5 \mathrm{mg}$ to $15 \mathrm{mg}$ per day) to facilitate clearance of the virus. The patient improved clinically and headaches, back pain and asthenia disappeared within three weeks. He was discharged without any clinical sequelae in early December, 74 days after he had presented with symptoms to the GP in Mali.

During follow-up, the patient did not report having had any neurological defects or seizures. Neurological and ophthalmologic examination remained within normal limits.
RT-PCR became negative on day 145 in semen i.e. four months after the first physician visit, and in urine on day 117 i.e. three months after the onset of symptoms (Table).

\section{Investigation into possible source of infection}

The investigation was limited to an interview of the patient. He arrived in Dionkoulané, Kayes region, $30 \mathrm{~km}$ south the Mauritanian border, in Mali, in mid-August 2015. He took care of his father's livestock i.e. sheep and donkeys. No deaths or abortions in these animals were reported. He stated that he may have been in contact with mice living in the area. He did not handle dead animals or abortion products. He consumed raw cow's milk with couscous for a wedding in mid-September, about four days before the onset of the symptoms. No other guests exhibited illness following the wedding.

\section{Background}

Rift Valley fever (RVF) is an arthropod-borne zoonotic viral disease affecting mainly domestic and wild ruminants, as well as humans. Outbreaks in humans have been reported in 19 countries across Africa, the Indian Ocean islands, and the Arabian Peninsula [4].

RVF virus is transmitted to humans and animals by (i) direct contact with sick or dead infected animals or their body fluids, (ii) consumption of raw milk or meat from infected animals, and (iii) occasionally by mosquito bites (Culex, Anopheles, Aedes) [5]. Livestock i.e. sheep and goats, are highly susceptible to the virus leading to frequent epizootics, causing deaths and abortions and a significant economic impact.

Human infection is typically either subclinical or associated with moderate to severe, non-fatal, febrile illness. Patients can also develop ocular and neurological lesions, hepatitis with hepatic failure or haemorrhagic syndrome associated with infection. Approximately 1 to $2 \%$ of RVF infections result in fatal haemorrhagic fever [6]. 


\section{Discussion and conclusion}

This case report highlights that RVF may be acquired in Mali and that the virus was detected in urine and semen after the onset of symptoms for up to three and four months, respectively, in an immunosuppressed patient.

This is to the best of our knowledge the first documented human case of symptomatic RVF acquired in Mali. However, results from a study in 1999 among slaughterhouse personnel working with cattle and sheep in Saudi Arabia during the Hajj, showed a high seroprevalence for workers from Mali [7] and the village where the patient was infected is $30 \mathrm{~km}$ south the Mauritanian border, where an outbreak of RVF in sheep and goats was declared in October 2015 [8]. To our knowledge, there was no ongoing outbreak, unusual die-off or abortion reported in livestock in the village during the period of the patient's stay but a silent circulation of the virus cannot be excluded [9]. The patient was frequently bitten by mosquitoes. He also reported raw milk consumption which is considered as a risk factor for human infection [10].

Given the massive affection of the liver, the possibility of acute hepatitis B was ruled out by the low HBV viral load detected by RT-PCR at $20 \mathrm{IU} / \mathrm{mL}$ or $1.3 \mathrm{log}$, corresponding exactly to the threshold of this technique and with no clinical or biological significance, in a patient with a cured hepatitis B. Furthermore, a test for HBV viral load done one month later, was negative.

This case demonstrates the difficulty in diagnosing a little known pathology. The initial clinical presentation was characteristic for acute hepatitis and four weeks later, the patient presented with a lymphocytic meningoencephalitis. The severity of the clinical picture may have been related to the necessary therapeutic immunosuppression in the kidney transplant recipient which might also have slowed down the clearance of the RVFV. We did not precisely identify the mode of infection, however, the time from raw milk consumption to symptom onset was approximately four days. Considering this, and the clinical course with hepatitis symptoms 12 days later, and meningoencephalitis 44 days after having visited the physician in Mali, this is in agreement with the incubation time in the literature $[5,6]$.

We report the first RVF viral RNA detection in urine and in human semen that did not have gross blood contamination. No information about infectivity could be determined as viral isolation failed. The RVFV was previously detected in cattle semen [10] but not in humans. Infectious Ebola virus can be present in semen more than three months after recovery and is transmitted to other persons by sexual route [11]. Similarly, Zika virus has been isolated from the semen of a patient 24 days post onset of symptoms [12]. Ebola virus RNA was detected more than nine months post-exposure [11]. Duration of virus persistence in semen may be linked to the immunosuppressive status of a patient or a viral characteristic as for Ebola and Zika virus. As a precaution, we recommend to abstain or engage only in protected intercourse when RVFV is detected in semen, until complete clearance of the virus.

RVFV genomic RNA was detected in semen four months after the onset of symptoms in an immunocompromised patient. Testing semen could be a new method for diagnosing RVF retrospectively and presence of RVFV genomic RNA raises the possibility that RVF could be transmitted sexually.

\section{Acknowledgements}

The authors would like to acknowledge Dr. Lucile Mercadal, Dr. Sophie Demeret for their contribution in this patient's medical care and Jeffrey Kugelman for English correction.

\section{Conflict of interest}

None declared.

\section{Authors' contributions}

Wrote the manuscript: $\mathrm{FH}, \mathrm{MM}$ and EC; performed laboratory investigations: MM and IL-G; was actively involved in the reflection on this case: $\mathrm{FS}$; revised the manuscript: FS and VMP; managed the patient and lead the epidemiological investigation: $\mathrm{FH}, \mathrm{MH}$ and $\mathrm{EC}$.

\section{References}

1. Peyrefitte CN, Pastorino BAM, Bessaud M, Gravier P, Tock F, Couissinier-Paris $P$, et al. Dengue type 3 virus, Saint Martin, 2003-2004. Emerg Infect Dis. 2005;11(5):757-61. DOI: 10.3201/ eid1105.040959 PMID: 15890134

2. World Health Organization (WHO). Guidelines for plaque reduction neutralization testing of human antibodies to dengue viruses [Internet]. Geneva: WHO. [Accessed 26 Apr 2016]. Available from: http://apps.who.int/iris/ bitstream/10665/69687/1/who_ivb_07.07_eng.pdf

3. Bird BH, Bawiec DA, Ksiazek TG, Shoemaker TR, Nichol ST. Highly sensitive and broadly reactive quantitative reverse transcription-PCR assay for high-throughput detection of Rift Valley fever virus.J Clin Microbiol. 2007;45(11):3506-13. DOI: 10.1128/JCM.00936-07 PMID: 17804663

4. Balenghien T, Cardinale E, Chevalier V, Elissa N, Failloux $A-B$, Jean Jose Nipomichene TN, et al. Towards a better understanding of Rift Valley fever epidemiology in the southwest of the Indian Ocean. Vet Res (Faisalabad). 2013;44(1):78 DOI: 10.1186/1297-9716-44-78 PMID: 24016237

5. Nicholas DE, Jacobsen KH, Waters NM. Risk factors associated with human Rift Valley fever infection: systematic review and meta-analysis.Trop Med Int Health. 2014;19(12):1420-9. DOI: 10.1111/tmi.12385 PMID: 25252137

6. World Health Organization (WHO). Rift Valley fever [Internet]. Geneva: WHO. [Accessed 19 Dec 2015]. Available from: http:// www.who.int/mediacentre/factsheets/fs207/en/

7. Turkistany A-H, Mohamed AG, Al-Hamdan N. SEROPREVALENCE OF RIFT VALLEY FEVER AMONG SLAUGHTERHOUSE PERSONNEL IN MAKKAH DURING HAJJ 1419h (1999).J Family Community Med. 2001;8(3):53-7.PMID: 23008651

8. ProMED-mail. Rift Valley fever - Mauritania: caprine, ovine, OIE; Oct 2015. Report No.: 20151107.3773966. Available from: http://promedmail.org/post/3773966

9. Nicolas G, Chevalier V, Tantely LM, Fontenille D, Durand B. A spatially explicit metapopulation model and cattle trade analysis suggests key determinants for the recurrent circulation of rift valley Fever virus in a pilot area of 
madagascar highlands.PLoS Negl Trop Dis. 2014;8(12):e3346.

DOI: 10.1371/journal.pntd.0003346 PMID: 25474116

10. The center for food security and public health, Institute for international cooperation in animal biologics. Infectious

Enzootic Hepatitis of Sheep and Cattle [Internet]. Iowa State

University: College of veterinary medicine; 2015 Jan p. 2. (Rift Valley Fever). Available from: http://www.cfsph.iastate.edu/ Factsheets/pdfs/rift_valley_fever.pdf

11. Rogstad KE, Tunbridge A. Ebola virus as a sexually transmitted infection.Curr Opin Infect Dis. 2015;28(1):83-5. DOI: 10.1097/ QC0.0000000000000135 PMID: 25501666

12. Musso D, Roche C, Robin E, Nhan T, Teissier A, Cao-Lormeau V-M. Potential sexual transmission of Zika virus. Emerg Infect Dis. 2015;21(2):359-61. DOI: 10.3201/eid2102.141363 PMID: 25625872

\section{License and copyright}

This is an open-access article distributed under the terms of the Creative Commons Attribution (CC BY 4.0) Licence. You may share and adapt the material, but must give appropriate credit to the source, provide a link to the licence, and indicate if changes were made.

This article is copyright of the authors, 2016. 